\title{
On the Effect of Linoleic Acid and Yeast upon the Growth of Rats on High Fat Diet.
}

\author{
By \\ Yoshikazu Sahashi. \\ (Received January 20, 1934.)
}

In a previous communication ${ }^{(1)}$ the present author reported the results of some feeding experiments on rats with synthetic diets containing large amounts of the oils obtained from sperm whale and fin-back whale.

Until recently, the chief physiological role assigned to dietary fats has been that of the fuel for the generation of energy, but certain unsaturated fatty acids are now recognized to be indispensable food factors like vitamins. The author, therefore, repeated some feeding experiments on rats using similar diets to those described in the previous paper but with the addition of linoleic acid and yeast.

Most of the rats in this experiment indicated almost normal growth, but no young were born during the entire feeding period except in the group supplied with butter. At the end of the experiment, the animals were killed and submitted to gross anatomical examination with the hope of determining the changes in sex glands. From this examination arose an unexpected discovery of the presence of vitamin $E$ in Japanese soy bean oil, the details of which are given in a separate paper. ${ }^{(2)}$

\section{Experimentel}

(I) Samples af Fats or Oils used in the Animal Experiments. Analysis of the samples used in the experiments :

\begin{tabular}{l|c|c|c|c|c|c}
\hline \multicolumn{1}{c|}{ Samples used } & Sp. gr. & Refr. index & $\begin{array}{c}\text { Acid } \\
\text { value }\end{array}$ & $\begin{array}{c}\text { Sap. } \\
\text { value }\end{array}$ & $\begin{array}{c}\text { Iod. } \\
\text { value }\end{array}$ & $\begin{array}{c}\text { Vitamin } \\
\text { Carotins }\end{array}$ \\
\hline Butter (Kin en) & - & - & - & - & - & ++ \\
Beef fat*** & - & - & 0.6 & 196.7 & 48.2 & - \\
Lard*** & $d_{4}^{15}=0.911$ & $n_{\mathrm{D}}^{26}=1.471$ & 0.8 & 195.3 & 15.9 & - \\
$\begin{array}{c}\text { Cod liver oil } \\
\text { (J. P. IV) }\end{array}$ & $d_{4}^{15}=0.927$ & $n_{\mathrm{D}}^{22}=1.475$ & 0.7 & 180.8 & 154.4 & +++ \\
$\begin{array}{c}\text { Blubber oil* } \\
\text { (Finback whale) } \\
\text { Intestine oil* } \\
\text { (Finback whale) }\end{array}$ & $d_{4}^{15}=0.917$ & $n_{\mathrm{D}}^{22}=1.466$ & 0.2 & 185.5 & 92.7 & - \\
\hline
\end{tabular}

These samples used in the experiments were kindly supplied by Toyo Hogei Kaisha* and Marumiya Company, ${ }^{* *}$ and the other one ${ }^{* * *}$ were prepared from fresh raw materials in our laboratory. 


\begin{tabular}{l|c|c|c|c|c|c} 
Soy bean oil & $d_{4}^{15}=0.937$ & $n_{\mathrm{D}}^{30}=1.481$ & 0.5 & 1914 & 142.5 & + \\
$\begin{array}{l}\text { White sesame } \\
\text { oil** }\end{array}$ & $d_{4}^{15}=0.926$ & $n_{\mathrm{D}}^{23}=1.471$ & 1.3 & 187.0 & 119.3 & - \\
Peanut oil*** & $d_{4}^{15}=0.920$ & $n_{\mathrm{D}}^{30}=1.475$ & 0.2 & 187.9 & 103.6 & - \\
Cocoa-nut oil** & $d_{4}^{15}=0.931$ & $n_{\mathrm{D}}^{23}=1.452$ & 36.9 & 262.1 & 11.5 & - \\
$\begin{array}{c}\text { Palm oil* } \\
\begin{array}{c}\text { Olive oil } \\
\text { (Betis spein) }\end{array}\end{array}$ & - & - & - & - & - & +++ \\
\hline
\end{tabular}

(II) Experiment with Diets Containing a Sufficient Quantity of Fats or Oils, without the Supplementary Feeding of Linoleic Acid.

Data on the growth of rats on high fat diets without the supplementary feeding of linoleic acid will be presented first.

Albino rats weighing 40 50 g each were previously fed for several days on a complete diet until they reached $50 \sim 60 \mathrm{~g}$. Then they were divided into several groups, each consisting of 4 rats, and were fed on various experimental synthetic diets (Charts 1 and 2). The diets consisted of:

$\begin{array}{lrr}\text { Potato starch (Japanese Pharmacopea) } & 65 \mathrm{~g} & 60 \mathrm{~g} \\ \text { Fish protein freed from fat } & 18 \mathrm{~g} & 15 \mathrm{~g} \\ \text { McCollum's salt mixture } & 15 \mathrm{~g} & 15 \mathrm{~g} \\ \text { Oryzanin solution (Sankyo \& Co.) } & 5 \mathrm{c.c} . & - \\ \text { Dricd yeast (Oriental C.) extracted with ether. } & - & 2 \mathrm{~g} \\ \text { Fat or oil } & 15 \mathrm{~g} & 20 \mathrm{~g} \\ \text { Biosterin dissolved in olive oil, given per os daily } & 1 \mathrm{mg} & 1 \mathrm{mg}\end{array}$

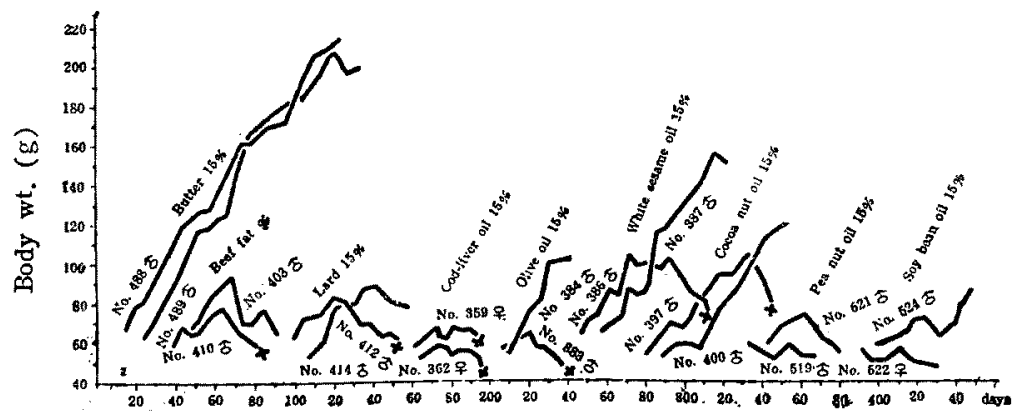

Chat 1. Growth curves of rats fed on the diets containing $15 \%$ fats or oils supplemented with oryzanin (without linoleic acid). 


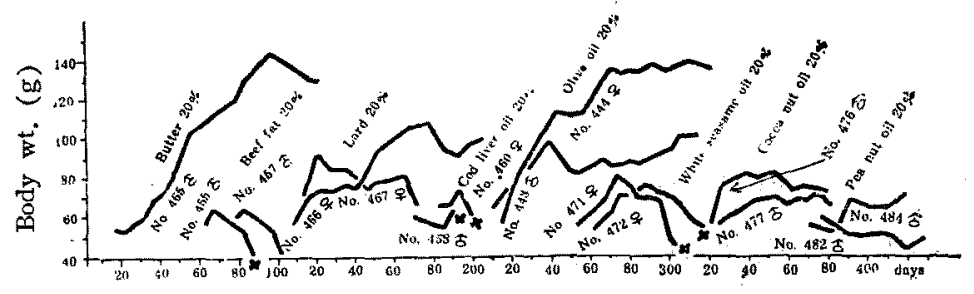

Chart 2. Growth curves of rats fed on the diets containing $20 \%$ fats or oils supplemented with dry yeast (without linoleic acid).

From the above experiment it can be seen that rats failed to grow satisfactorily on any of the diets, except on the one containing butter. Slight seborrhea was observed in some of these rats (Photo. 3).

(III) Effect of Linoleic Acid and Yeast upon the Growth of Rats fed on High Fat Diets.

We now come to the main experiment which was conducted to see the effect of linoleic acid and yeast on the growth of rats fed on high fat diets, linoleic acid being now recognized as an indispensable food factor like a vitamin.

The diets used were similar to the preceding experiment: Potato starch $65 \mathrm{~g}$, fish protein $15 \mathrm{~g}$, McCollum's salt mixture $4 \mathrm{~g}$, dry yeast extracted with ether $2 \mathrm{~g}$, fat or oil $15 \sim 20 \mathrm{~g}$, and in addition biosterin $1 \mathrm{mg}$ and pure

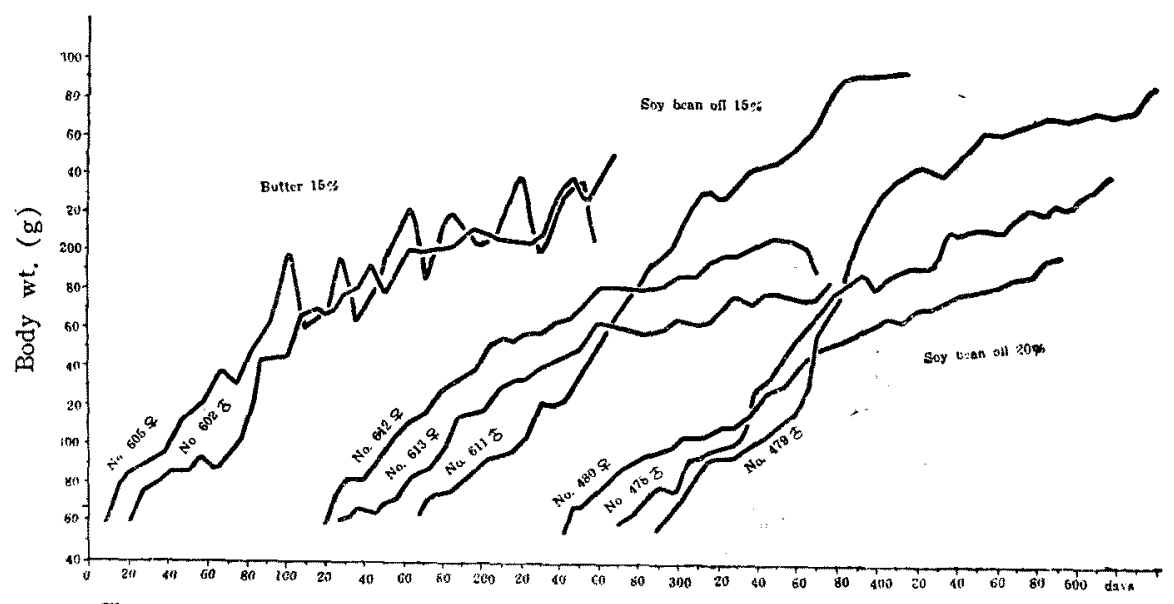

Chart 3. Growth curves of rats fed on the diets containing 15 20\% butter or soy bean oil supplemented with yeast and without linoleic acid. Linoleic acid was not added since butter as well as soy bean oil naturally contains this fatty acid. 


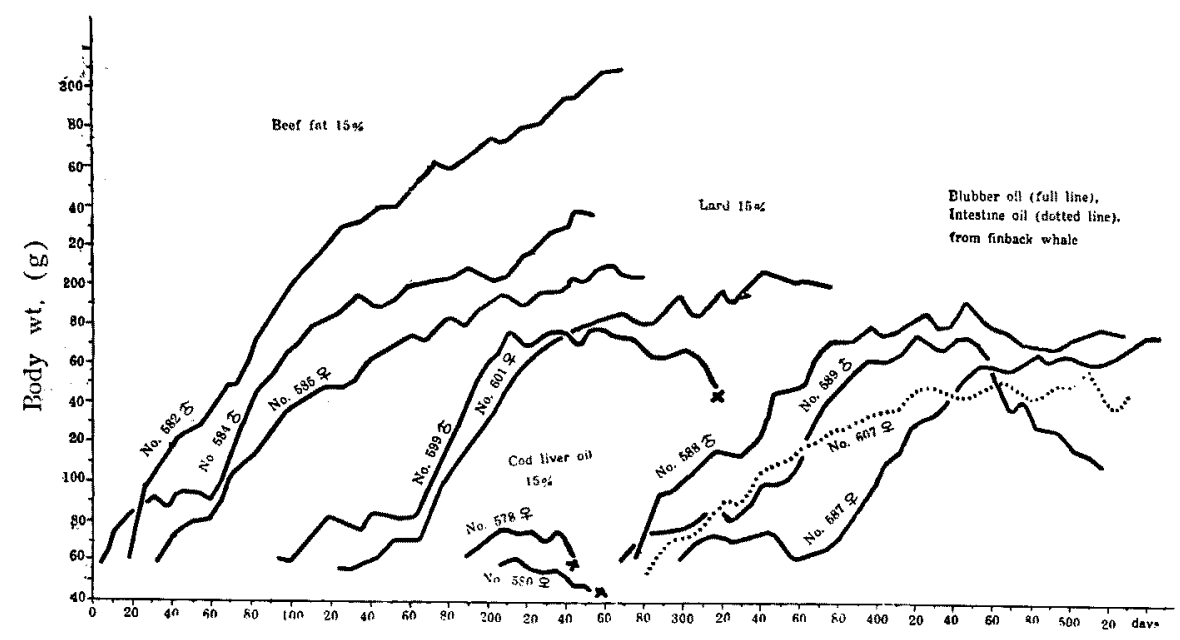

Chart 4 Growth curves of rats fed on the diets con aining $15 \%$ animal fats or oils supplemented with yeast and linoleic acid.

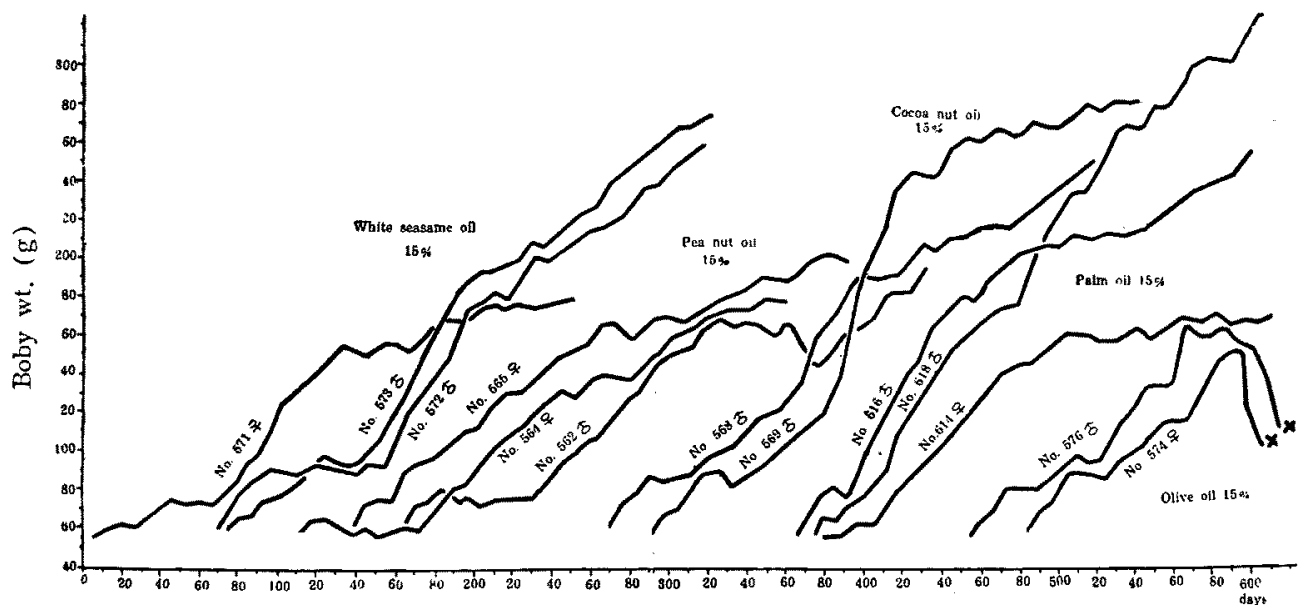

Chart 5. Growth curves of rats fed on the diets containing $15 \%$ vegetable fats or oils supplemented with yeast and linoleic acid.

linoleic acid $50 \sim 100 \mathrm{mg}$ being supplied per os to every rat daily.

The rats given cod liver oil died after 50 days, but, on the contrary, those supplied with other oils and fats lived more than 250 days and secured nearly the normal growth (Charts $3 \sim 5$ and Photo. 1, 2 and 4 ).

From the anatomical examination made on the rats at the termination of this experiment, the absence of vitamin $\mathrm{E}$ was recognized in all the above fats and oils except butter and soy bean oil. The evidence for the presence of vitamin $\mathrm{E}$ in soy bean oil is given in a separate paper. ${ }^{(2)}$ 


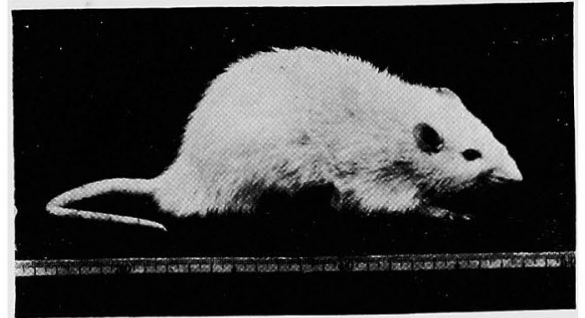

Photo. 1. Rat (No. 611 $\delta$ ) supplied with yeast in addition to $15 \%$ soy bean oil. Body weight $288 \mathrm{~g}$ at the 240 th day of experiment.

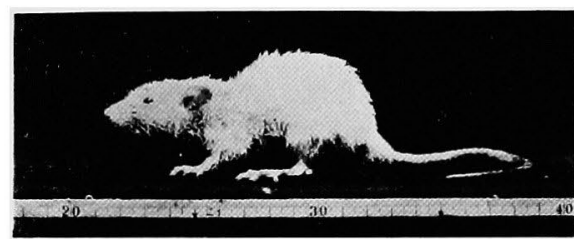

Photo. 3. Slight seborrhoea in rat (No.410 $\delta$ ) fed with beef fat without yeast or linoleic acid. Body weight $59 \mathrm{~g}$ at the 45 th day.

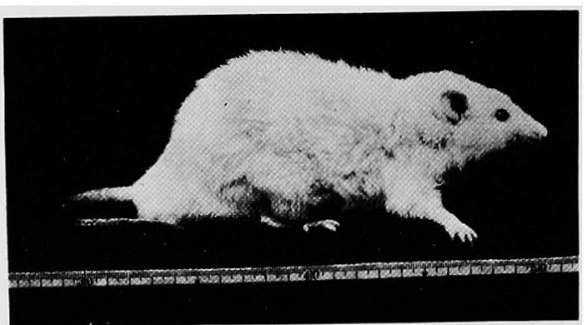

Photo. 2. Rat (No. 618 o ) supplied with linoleic acid and yeast in addition to $15 \%$ palm oil. Body weight $302 \mathrm{~g}$ at the 210 th day.

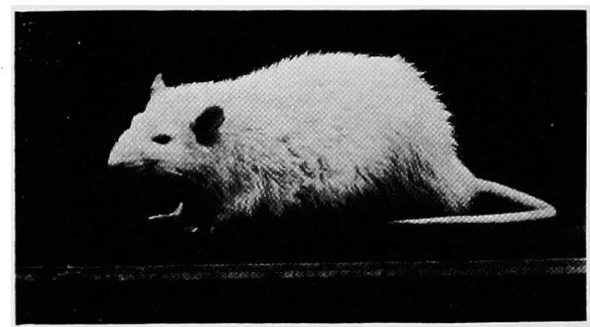

Photo. 4. Rat (No. $582 \hat{\text { ) }}$ supplied with yeast and linoleic acid in addition to $15 \%$ beef fat. Body weight $310 \mathrm{~g}$ at the 240 th day.

\section{Summary}

Albino rats failed to secure satisfactory growth on diets containing a high percentage of any of the fats used except butter. The addition of yeast to the diet did not improve the growth of the animals. With the supplementary feeding of linoleic acid in addition to yeast the animals attained nearly the normal rate of growth, demonstrating anew the importance of linoleic acid as a dietary element.

The author expresses his sincere thanks to Prof. U. Suzuki for his kind advice and encouragement throughout the progress of this work.

\section{Literature.}

(1) Y. S.hashi: Sc. Pap. I. P. C. R., 20, 245 253, (1933); Bull. Agr. Chem. Soc., Vol. 9, 69 (1933).

(2) U. Suzuki, W. Nakahara, and Y. Sahashi: Sc. Pap. I. P. C. R., 23, No. 491, 270, (1934); Bull. Agr. Chem. Soc., Vol. 10, 87 (1934). 